\title{
PRAVNI ASPEKTI PANDEMIJE COVID-19 I UTICAJ NA POSTUPAK PRED KOŠARKAŠKIM ARBITRAŽNIM TRIBUNALOM (BAT)
}

\begin{abstract}
Uroš BAJOVIĆ*
Apstrakt: Košarkaški arbitražni tribunal je međunarodno arbitražno telo oformljeno za rešavanje ugovornih sporova koji nastaju u košarkaškoj sportskoj industriji. BAT je već značajno slavljena arbitraža koja je dala veliki doprinos uređivanju pravnih odnosa u košarci kao profesionalnom sportu. Nove okolnosti u vidu globalne pandemije korona virusa stavile su ovu arbitražu na još jedan značajan ispit, a rezultati rada i odabranih rešenja i dalje podležu različitim mišljenjima i tumačenjima. BAT poseduje kvalitet organizacione nezavisnosti u odnosu na svetsku kuću košarke FIBA, ali postoji i rešava sporove u sadejstvu i pod pokroviteljstvom ove krovne organizacije. Efekti rada BAT-a pre pandemije su nesporni, a najčešće se njegove vrednosti opisuju kroz brzo, efikasno i sigurno rešavanje sporova sa jednostavnim BAT pravilima arbitraže koja podrazumevaju postojanje rešenja koja maksimalno ubrzavaju i pojednostavljuju sam postupak pred jednim arbitrom. Odluka Tribunala ima snagu presuđene stvari, a načelo po kojem se rešavaju sporovi je, u osnovi, načelo pravičnosti. Pre globalne pandemije korona virusa izgrađena je respektabilna praksa u rešavanju sporova, a slična praksa je nastavljena i na osnovu korišćenja uputstava koja su objavljena već u prvom dvomesečju pandemije. Upravo su ova pravila, njihovi efekti i opšti uticaj globalne pandemije na košarkašku sportsku industriju predmet istraživanja ovog rada.

Ključne reči: Košarkaški arbitražni tribunal, BAT, Covid-19 Uputstva, Međunarodna košarkaška federacija, BAT arbitražna pravila, ECA i ELPA sporazum.
\end{abstract}

\section{1) UVOD}

Skoro 40 godina nakon nastanka košarke kao sporta, 1932. godine, u Ženevi je osnovana Međunarodna košarkaška federacija - FIBA (Fédération Internationale

\footnotetext{
* Pravni fakultet Univerziteta u Beogradu.

E-mail: bajovicuros@hotmail.com

Pogledi izneti u članku odražavaju lični stav autora, a ne stav institucije.
} 
de Basketball), koja je priznata od strane Međunarodnog olimpijskog komiteta kao jedini apsolutni autoritet za košarku na celom svetu. ${ }^{1}$ FIBA svoj globalni karakter potvrđuje članstvom čak 213 nacionalnih košarkaških federacija. Osnovni ciljevi FIBA su regulacija, kontrola, nadzor i usmeravanje košarkaškog sporta u svim uzrastima i podjednako u smislu muškog i ženskog košarkaškog sporta. ${ }^{2} \mathrm{Na}$ tim temeljima, u skladu sa potrebama očuvanja pravilnosti i zakonitosti u košarci, Statut FIBA navodi da je ona odgovorna za osnivanje i upravljanje košarkaškim sudskim sistemom osposobljenim za rešavanje sporova, kao i za ulaganje prigovora i žalbi. ${ }^{3}$

U skladu s tim potrebama, 2006. godine formiran je FIBA arbitražni tribunal „FIBA Arbitral Tribunal - FAT”. Već 2010. godine ovaj Tribunal je u skladu sa Generalnim Statutom FIBA od 2010. godine evoluirao u formu koja je i danas aktuelna - Košarkaški arbitražni tribunal „Basketball Arbitral Tribunal - BAT”. Odluke BAT-a su izvršive u skladu sa pravilima švajcarskog prava i Njujorške konvencije o priznanju i izvršenju stranih arbitražnih odluka. ${ }^{4}$ Sedište arbitraže je u Ženevi, Švajcarska.

Rešavanje sporova nastalih iz ugovora igrača i stručnih štabova u košarci se danas, u najvećoj meri, oslanja na poverenje u pravičnost i način rada ovog košarkaškog arbitražnog tela. Gotovo svi košarkaški radnici, bilo neposredni učesnici košarkaških događaja poput trenera, stručnih štabova i igrača, ili oni koji predstavljaju drugi stub sportske industrije poput košarkaških agenata, generalnih menadžera klubova ili sportskih direktora, iskazuju pozitivan stav prema radu Tribunala i najčešće mu se obraćaju, a sve u skladu sa načelima po kojima ovo arbitražno telo funkcioniše. Interes i poverenje u košarkaški arbitražni tribunal možemo pronaći već u preambuli Arbitražnih pravila BAT-a. ${ }^{5} \mathrm{U}$ tom smislu, tačka 0.2 Preambule navodi da su arbitražna pravila BAT-a nastala sa željom da obezbede jednostavno, brzo i jeftino rešavanje sporova. Ova pravila arbitraže se zasnivaju na saradnji između stranaka, sa ograničenim brojem pisanih podnesaka i kraćim vremenskim rokovima za njihovo razmatranje. ${ }^{6}$ Načelo efikasnosti, uz načelo pravičnosti u rešavanju sporova, predstavljaju ključna načela Košarkaškog arbitražnog tribunala. Sva osnovna pravila ove arbitraže, kao što je već

\footnotetext{
1 „Statut Međunarodne košarkaške federacije FIBA“, Međunarodna košarkaška federacija (FIBA), član 1, stav 1.2, Mies, Švajcarska, 29. avgust 2019.

${ }^{2}$ Ibid., član 4, stav 4.1.

${ }^{3}$ Ibid., član 1 , stav 1.2 , tačka $h$.

${ }^{4}$ „Federalni zakon o međunarodnom privatnom pravu PILA“, Federalna skupština Švajcarske, članovi 176-194, Švajcarska, 1. januar 2017.

5 „BAT arbitražna pravila“, preambula, Basketball Arbitral Tribunal, 1. januar 2017.

${ }^{6}$ Stefan Andonović, Uroš Bajović, „Postupak pred košarkaškim arbitražnim tribunalom (BAT)“, Strani pravni život, 62(2), 2018, str. 207.
} 
napomenuto, usmerena su ka što bržem i jednostavnijem rešavanju sporova. Ističu se po jednom arbitru u svakom sporu, kratkim rokovima, izostanku saslušanja i brzom donošenju odluka. U preambuli arbitražnih pravila pružen je i predlog BAT arbitražne klauzule za koju je potrebno da pronađe svoje mesto kao deo ugovora strana, da bi se mogla ustanoviti kasnija nadležnost BAT-a: „Svaki spor koji nastane iz ili je u vezi sa postojećim ugovorom će se rešavati pred košarkaškim arbitražnim tribunalom (BAT) u Ženevi, Śvajcarska, i biće rešen u skladu sa BAT arbitražnim pravilima od strane jednog arbitra kojeg određuje predsednik BAT-a. Jezik na kojem će se arbitraža održati je engleski. Arbitar će odlučivati u sporu u skladu sa ex aequo et bono".7 Arbitražna pravila BAT-a se primenjuju za sva pitanja (predviđena njima), a za sva ostala pitanja primenjuju se odredbe glave 12 Svajcarskog federalnog zakona o međunarodnom privatnom pravu. U ovom zakonu sadržano je i neobično arbitražno rešenje koje predviđa mogućnost ulaganja žalbe na odluku arbitraže Vrhovnom federalnom sudu Švajcarske. ${ }^{8}$ Ipak, ova odredba u pogledu košarke kao sportske industrije i njenih sporova predstavlja više kuriozitet, nego neku praktičnu vrednost.

Košarkaški arbitražni tribunal je, po opšteprihvaćenom mišljenju, pružio adekvatnu zaštitu neposrednim proizvođačima u ovom sportu i na pravi način odgovorio na izazove izazvane nepoštovanjem ugovora. Pre osnivanja BAT-a igrači, članovi stručnih štabova i agenti najčešće su bili oštećene strane, bez efikasnih mehanizama za brzu zaštitu svojih prava. Ugovorna praksa u košarci kao profesionalnom sportu u današnjem vremenu pokazuje da je prihvaćenost nadležnosti ove košarkaške arbitraže preko $95 \%$ u ugovorima igrača i članova stručnih štabova, što predstavlja najbolji odgovor na pitanje da li je ideja koja datira još od 2006. godine, a revidirana 2010, pružila u potpunosti adekvatan odgovor na kriznu situaciju. U skladu s tim, kao i sa činjenicom da Košarkaški arbitražni tribunal pokriva isključivo arbitražne postupke proistekle iz košarke kao profesionalnog sporta, postoje tvrdnje nekih autora da on predstavlja „izuzetno uspešan eksperiment".

Globalna pandemija korona virusa je, poput „pandemije povreda ugovora“ $u$ ranijem periodu izazvala potrebu za adekvatnom reakcijom Košarkaškog arbitražnog tribunala. U skladu sa reputacijom ove arbitražne institucije ova reakcija je usledila vrlo brzo, već u sklopu prva dva meseca od preseljenja velikog broja slučajeva korona virusa na tlo Evrope. BAT Covid-19 Uputstva se izdaju već 20. aprila 2020. godine, a u tom trenutku je velika većina nacionalnih i

\footnotetext{
${ }^{7}$ Ibid., str. 209; „BAT arbitražna pravila“, preambula, član 0.3, 1. januar 2017.

8 „Federalni zakon o međunarodnom privatnom pravu PILA“, op. cit., član 191.

${ }^{9}$ Erika Hasler, "The Basketball Arbitral Tribunal - An Overview of Its Process and Decisions", in: Antoine Duval and Antonio Rigozzi (eds.), Yearbook of International Sports Arbitration 2015, Hague, Springer, 2016, p. 113.
} 
kontinentalnih klupskih košarkaških takmičenja obustavljena. ${ }^{10}$ Košarkaška liga Turske je najduže odolevala, ali se i ovo takmičenje obustavilo početkom maja meseca. U takvoj situaciji je bilo jasno da nad ugovorima igrača, stručnih štabova i provizija agenata lebde sivi ili crni oblaci potencijalnog neispunjenja i da je ugroženost neposrednih (i posrednih) proizvođača u industriji košarke kao profesionalnog sporta izuzetno velika. Ne ulazeći na ovom mestu duboko u uspeh i adekvatnost ovog Covid-19 Uputstva BAT, potrebno je ukazati na mnoštvo otežavajućih okolnosti sa kojima se ova arbitraža suočila. Globalna pandemija korona virusa je predstavljala, kako činjenično tako i pravno, novu situaciju u kojoj su svi akteri košarke kao profesionalnog sporta na velikom gubitku. Ogromne novčane udare trpe vlasnici, glavni i manji sponzori klubova, jer navijači, bez kojih posebno evropski košarkaški sport nema smisla, bivaju udaljeni iz hala i u stalnoj brizi za sopstveno zdravlje i ekonomski opstanak, dok neposredne proizvođače (igrače, trenerske i skauting štabove), kao i agente vezuju ugovori potpisani pre stupanja na snagu crnog scenarija globalne pandemije. ${ }^{11}$

U takvoj situaciji bilo je jasno da je Košarkaški arbitražni tribunal institucija u koju je uperen najveći broj pogleda ka potencijalnom donošenju nekih održivih rešenja, u kojima bi svi akteri, srazmerno svojoj ugroženosti i ekonomskoj moći, bili adekvatno zaštićeni i uz pomoć kojih bi se arbitražno, ili bez ikakvog spora, održalo načelo pravičnosti, jedno od krunskih načela postupaka pred Košarkaškim arbitražnim tribunalom.

\section{2) EFEKTI GLOBALNE PANDEMIJE NA KOŠARKU KAO PROFESIONALNI SPORT}

Posledice globalne pandemije korona virusa na sport u celini su sveobuhvatne i dalekosežne, a njihov domet je još nemoguće precizno proceniti. ${ }^{12} \mathrm{Na}$ isti način, ako ne i snažnije, globalna pandemija Covid-19 uticala je i na košarku, koja van američke profesionalne lige (NBA) uglavnom spada u „neprofitabilne“ sportove, odnosno sportove u kojima je izdržavanje sportskog kolektiva bez pomoći države (indirektne), sponzora ili prijatelja sporta nemoguće. Evropska košarka, u celini, u potpunosti predstavlja takav sport. Dovoljno je uraditi kraću analizu funkcionisanja najboljih evropskih timova i utvrditi da iza nekoliko stoji moćan i uspešan fudbalski klub koji predstavlja finansijera i fabriku novca (Real Madrid, Barselona, Bajern i

10 "BAT Covid-19 Uputstva”, Basketball Arbitral Tribunal, Minhen, Nemačka, 20. april 2020.

${ }^{11}$ Sara Keshar, Geoff Dickson, Aila Ahonen, "The Effects of Coronavirus Pandemic on the Sports Industry: An Update”, Ann Appl Sport Sci 9(1): e964, NY, USA, 2021, pp. 5-7.

${ }^{12}$ Zapisi sa panela organizovanog od strane Wagner Arbitraže dostupni su na internetu. "Covid19 and Sports Law - The Stakeholders' legal perspectives", https://wagner-arbitration.com/ en/journal/covid-19-and-sports-law-the-stakeholders-legal-perspectives/, 26.2.2021. 
mnogi drugi), iza nekih drugih državno-privatno partnerstvo i sponzorstvo (CSKA Moskva sa rudarskom kompanijom ili Baskonija sa direktnom poveznicom prema jednoj od najmoćnijih španskih finansijskih institucija), dok iza poslednjih stoje košarkaške mecene koji svoje lično bogatstvo ili bogatstvo svojih kompanija stavljaju na raspolaganje košarkaškom kolektivu. Takvi primeri su italijanski velikani Olimpija Milano i Virtus Bolonja, grčki Panatinaikos i Olimpijakos, ili Cedevita Olimpija iz regije Balkana. U takvoj situaciji efekat korona virusa je lako razumljiv, u smislu da se finansijski udarci za košarku kao profesionalni sport mogu očekivati iz svih pravaca, gde faktički postoji znak jednakosti između ugrožene i urušene ekonomije (bilansa kompanije, fudbalskog kluba ili bogatog finansijera) i finansijske stabilnosti košarkaških klubova. ${ }^{13}$ Dodatno, izuzetno otežavajuća okolnost i jedan od osnova koji je kasnije otvorio pitanja kojima se, delom, i ovaj rad bavi je faktor iznenađenja sa kojim se globalna pandemija korona virusa pojavila, gde nikakva priprema ili mehanizam nisu postojali da ublaže jak ekonomski, finansijski, a ubrzo i pravni udar na sport.

Iznenadno i neočekivano izbijanje korona virusa u svetu izazvao je ozbiljnu krizu u celokupnoj sportskoj industriji. Poznato je da je strah od virusa i nepripremljenost na novu situaciju izazvao obustavljanje svih pokrenutih sportskih aktivnosti u prošloj takmičarskoj godini. U velikom delu sveta važile su mere ograničenja kontakata i kretanja. U takvim okolnostima klubovi nisu mogli da održavaju svoje redovne dnevne aktivnosti, pa su bili zatvoreni. Sportska industrija i njen finalni produkt, u slučaju košarke - utakmice i treninzi, bili su stavljeni u drugi plan, a čitavim profesionalnim sportom je zavladala kako ekonomska, tako i pravna neizvesnost. Finansijski gubici su se merili bilionima evra/dolara, a ekonomski (ubrzo i zdravstveni) udarac virusa pretrpeli su svi nivoi angažovanih u košarci kao profesionalnom sportu - od vlasnika, preko sportskih sektora, samih aktivnih sportista i trenerskih (stručnih) štabova. Takva situacija je izrodila ingeniozna rešenja koja su košarci omogućila opstanak - rešenje je pronađeno u još jednom spoju moderne tehnologije i sportskih događaja, gde se teren svih sportskih dešavanja preselio u virtuelni svet i svet prenosa, gde je broj stvarno prisutnih učesnika sportskog događaja sveden na minimum, dok su svi ostali svoju konzumaciju sporta nastavili na internet/TV mreži, često i jako udaljeni od stvarnog dešavanja. ${ }^{14} \mathrm{U}$ osnovi, ovakav sistem prenosa nije uopšte nepoznat, a realizuje se od sredine prošlog veka. Međutim, globalna pandemija korona virusa je čitav sistem

\footnotetext{
${ }^{13}$ Jenisej Krnjaic, "The Impact of Covid Crises on the Sport Industry", https://miuc.org/impactcovid-crisis-sport-industry/, Marbella International University Centre, 1.3.2021.

14 "The Future of Sports: How the Roles of Athletes, Fans and Industry Businesses Will Change After Covid-19", https://www.uschamber.com/on-demand/coronavirus-pandemic/thefuture-of-sports-how-the-roles-of-athletes-fans-and-industry-businesses-will-change-aftercovid-19, US Chamber of Commerce, 1.3.2021.
} 
televizijskih i internet prenosa dovela na mnogo viši nivo, gde su neposredni sportski akteri ostavljeni potpuno usamljeni na sportskom terenu, ali pod budnim okom kamera. ${ }^{15} \mathrm{Na}$ sličnoj osnovi, a sve u cilju minimizovanja ekonomske i emocionalne štete, uspešno su funkcionisali tzv. „Baloni“, gde je na najvišem nivou organizovan NBA Balon, a pre njega vrlo uspešno i evropski baloni u kojima su završene španska i nemačka košarkaška liga.

Ovakva rešenja takmičenja pred praznim tribinama, bez neposrednog prisustva navijača i medija, pružila su određenu priliku za umanjenje štete nanete sportskoj industriji. Košarka se uz škripu patika ipak vratila na scenu, a klubovi, igrači, sportski sektori i stručni štabovi su se vratili obavljanju svog posla sa nadom da je organizacija nove sezone moguća i realna. U praksi, stručnjaci za menadžment, marketing i ekonomiju uspeli su da ožive sportskog džina, ali su posledice u pravnom smislu ostale duboke i bez adekvatnog rešenja, sa nekoliko konkurentnih mišljenja i predloga.

Košarka, kao profesionalni sport, bila je izuzetno pogođena od samog početka pandemije iz brojnih razloga. Najveći broj košarkaških mečeva se održava u halama, tj. zatvorenom prostoru, dok sam sport spada u grupu kontaktnih sportova. Samim tim, bilo je nemoguće propisati i sprovesti adekvatnu fizičku distancu, kako na tribinama tako i na terenu, posebno u trenucima kada je bilo brojnih nepoznanica o načinu širenja virusa, kao i efektima zaštitnih maski. Lokalne i državne vlasti većine zemalja su odmah zabranile održavanje svih sportskih događaja (posebno sa odlikama kakve ima košarka), dok je dodatni udarac košarka, posebno u Evropi, doživela zabranom putovanja. Ovakve odluke i zdravstvena situacija nedvosmisleno su ostavile direktne posledice na čitav sistem košarke kao profesionalnog sporta, a od prvog dana pandemije su se naslućivale mogućnosti nastanka brojnih pravnih sporova na osnovu činjenice delimičnog ili potpunog nepoštovanja ugovora, kao i sporova iz oblasti radnog prava u širem smislu. Sva ova pitanja ostavila su otvorene probleme, ali i potrebu osnovnog regulisanja. S tim u vezi, relativno brzo od početka pandemije, u smislu svetske (evropske) košarke, reagovali su i Košarkaški arbitražni tribunal i Evroliga, kao organizacija za takmičenje najboljih klubova Evrope. ${ }^{16}$

\section{3) ANALIZA SPORAZUMA ECA/ELPA I BAT COVID-19 UPUTSTVA}

Pre detaljne analize BAT Covid-19 Uputstava, na ovom mestu, potrebno je ukazati i na pravno (ne)obavezujući sporazum postignut između Udruženja

\footnotetext{
${ }^{15}$ Sven Burchartz, Natalie Lasek, "The disruptive Effect of Covid-19 on the sports industry", https://www.lexology.com/library/detail.aspx?g=37b579ff-a3f2-4cf1-909e-7e05a4c39c0f , Lexology, 1.3.2021.

16 "BAT Covid-19 Uputstva", op. cit.
} 
košarkaša Evrolige (ELPA) i Evroligaških klubova u kojem su, na početku pandemije, date smernice kako bi trebalo da se obe strane ponašaju prema novonastaloj situaciji. ${ }^{17}$ Domen sporazuma se odnosi na završetak sezone 2019/20, čime je jasno ukazano na njegov vremenski ograničeni karakter i ovaj sporazum se sastoji od dva osnovna elementa - rešavanja problema smeštaja igrača i stručnih štabova/njihovog prava na povratak kući dok je sezona suspendovana i važenja ugovora. U pogledu ispunjenja ugovora, ELPA i Evroliga dogovorile su, u tom trenutku, maksimalno poštovanje neposrednih proizvođača (igrača i stručnih štabova), ali uz uzimanje u obzir faktora višestruke štete i izgubljene dobiti vlasnika klubova. Tako su u ovom sporazumu predviđene dve potencijalne solucije - prva, koja je predviđala nastavak sezone kad se ispune zdravstveni i pravni uslovi, i druga, koja je predviđala definitivan kraj sezone. Razlika u solucijama se ogledala u iznosu garantovane plate neposrednih proizvođača (85\% i 80\% od ukupne vrednosti ugovora), ali i u pogledu vremenskog važenja ugovora. Prva opcija podrazumevala je produženje važećih ugovora za još mesec dana, dok je druga predviđala da ugovori, već u trenutku donošenja odluke, prestaju da važe iz ugla Evrolige. U oba slučaja, kao krajnji rok za izmirenje obaveza prema neposrednim proizvođačima određen je 15. avgust 2020. godine. Ovaj sporazum ELPA i Evrolige predvideo je, pored izloženog, rešenje i za višegodišnje ugovore igrača, u kojima faktički ne bi bilo izmena - važili bi od 1 . jula 2020. godine.

Ovakav sporazum Unije igrača Evrolige i samog organizatora takmičenja naišao je na pozitivan stav obe strane, uredivši odnose jednostavno i precizno, ne ostavljajući puno prostora pravnim nedoumicama. Kao što je poznato, sezona u Evroligi nije nastavljena, ali i ovaj sporazum je ostao, bez sumnje, tek ograničenog značaja. Pored pravnog karaktera (ne)obaveznosti, on se pokazao nedovoljno opširnim i slabog obuhvata pošto se odnosio samo na igrače i stručne štabove sa jedne, i klubove sa druge strane članove evropskih takmičenja pod okriljem Evrolige, ali u nedovoljnoj meri i prema njima. Svi pomenuti klubovi se, pored evropskih takmičenja, bore i u nacionalnim šampionatima pod okriljem FIBA, tako da je, usled odnosa FIBA i Evrolige, ostalo mnogo nerešenih pitanja i nesigurnosti u pogledu radnih prava neposrednih proizvođača i sigurnosti njihovih, ranije potpisanih ugovora. Iz tih razloga, kao osnovni akt za razumevanje rešavanja situacije koju je izazvala globalna pandemija korona virusa u košarci kao profesionalnom sportu uzimaju se Covid-19 Uputstva Košarkaškog arbitražnog tribunala, zajednički izdata 20. aprila 2020. godine od strane predsednika, potpredsednika i arbitara BAT-a.

17 "ECA Shareholders Executive Board approves ELPA settlement agreement, draft dates for potential season resumption", https://www.euroleaguebasketball.net/euroleague-basketball/ news/i/ajnrwjw914m5nm3t/eca-shareholders-executive-board-approves-elpa-settlementagreement-draft-dates-for-potential-season-resumption, Euroleague Basketball, 3.3.2021. 
Izuzetno teška situacija izazvana globalnom pandemijom korona virusa izazvala je brojne mere u zaštiti stanovništva od zarazne bolesti, ali i medicinskih sistema i država od pucanja. Ovakve mere imale su dalekosežne negativne posledice na mnoga osnovna prava čoveka, ali i ekonomski na gotovo sve grane industrije, biznisa i ukupno tržišta rada kao takvog. U skladu sa ovim posledicama, javljaju se i one direktno ili indirektno vezane za košarku kao profesionalni sport, što je izazvalo brojne pravne nedoumice u pogledu važenja ugovora u profesionalnoj košarci, posebno u pogledu (finansijskih) odnosa igrača, trenera i klubova. U skladu sa izloženim, predsednik, potpredsednik i arbitri Košarkaškog arbitražnog tribunala su, na osnovu člana 16.1 arbitražnih pravila BAT-a, diskutovali i doneli set pravila (Uputstava) u pogledu ove situacije, ne odstupajući od osnovnih načela ove košarkaške arbitraže ex aequo et bono i pacta sunt servanda. Predsednik, potpredsednik i arbitri BAT-a su ova Uputstva izdali sa pet jasnih usmerenja u njihovom uvodu, čuvajući bogatu praksu ove arbitraže i misleći o globalnoj pandemiji korona virusa kao vremenski ograničenom stanju. ${ }^{18}$

Prvo od ovih pet usmerenja jasno ukazuje da su ova Uputstva BAT-a vremenski ograničenog važenja, omeđenog krizama ugovora po izbijanju globalne pandemije. U vezi s tim je i četvrto usmerenje da ova uputstva ne predstavljaju izmene ili zamenu postojećih arbitražnih pravila, kao i peto u kojem se jasno podvlači da će ova usmerenja biti predmet stalnog praćenja i predmet mogućih prilagođavanja u skladu sa razvojem situacije. Pored ovih usmerenja vezanih za vremenski karakter važenja i sam privremen karakter uputstava, još dva se odnose na očuvanje nezavisnosti arbitara i sam neobavezni karakter ovih uputstava. Ova pojašnjenja predstavljaju značajan kvalitet Covid-19 Uputstava jer njima ni na koji način nije ugrožena bogata praksa i višegodišnji uspešan rad arbitara. Sama Uputstva, u tački jedan, daju definiciju na koji se vremenski period odnose, definišući „period zaključavanja" kao onaj koji podrazumeva period između dana suspenzije/ završetka sezone u okviru nacionalnog šampionata i dana kada je prvenstvo nastavljeno, odnosno poslednjeg dana prvenstva po rasporedu pre globalne pandemije korona virusa, u slučaju da nacionalni šampionat nije nastavljen. ${ }^{19}$ Ovako omeđeni period, još jednom, jasno ukazuje svim zainteresovanim stranama da Covid-19 Uputstva BAT-a imaju važenje samo u konkretnoj situaciji, bez pretenzija ka izmeni ili korigovanju BAT arbitražnih pravila, što potvrđuje četvrtu tačku iz uvoda ovih pravila. Drugo ograničenje obuhvata BAT Covid-19 Uputstva i odnosi se na krug ugovora na koji se ova uputstva primenjuju. Iz njega su isključeni svi ugovori koji su potpisani nakon početka „perioda zaključavanja“. ${ }^{20}$ Prema

\footnotetext{
18 "BAT Covid-19 Uputstva”, op. cit. Pet uvodnih tačaka dokumenta, koje predstavljaju usmerenje postupanja u trenucima krize.

${ }^{19}$ Ibid., tačka 1.

${ }^{20}$ Ibid., tačka 6.
} 
Uputstvima BAT-a, za ove ugovore će se podrazumevati da su sve efekte krize izazvane globalnom pandemijom korona virusa uzeli u obzir. Pored ugovora potpisanih nakon početka „perioda zaključavanja“ iz primene ovih Uputstava izuzeti su i oni koji su produženi nakon početka „perioda zaključavanja“. U ovom krugu ugovora nalaze se oni koji su poznati kao „opcija“ na strani bilo kluba, bilo neposrednih proizvođača.

\subsection{PRIORITET PRIJATELJSKOG PORAVNANJA}

U odeljku II Covid-19 Uputstava BAT-a određen je prioritetni način rešavanja svih ugovornih sporova nastalih u košarci kao posledica globalne pandemije korona virusa. Ovaj način podrazumeva prijateljsko poravnanje, odnosno davanje prednosti dogovoru između strana naspram korišćenja usluga Košarkaškog arbitražnog tribunala. ${ }^{21}$

U tački 2 Covid-19 Uputstava BAT-a ustanovljava se dužnost stranaka da ponovo pregovaraju o svim tačkama ugovora, da bi zajednički rešili sve ugovorne nedoumice i probleme nastale izbijanjem globalne pandemije. Ova odredba ne predstavlja obavezu stranaka stricto sensu, ali će izostanak pokušaja prijateljskog poravnanja i postupanja u dobroj veri u tom procesu arbitar uzeti u obzir, ukoliko se stranke ipak odluče za usluge Tribunala. Arbitar tumači i ceni izostanak želje za prijateljskim poravnanjem jedne ili obe strane ne samo u pogledu merituma spora, već i u pogledu procesnih elemenata i troškova. ${ }^{22}$

Značaj prijateljskog poravnanja stranaka je dodatno pojačan odredbom iz tačke 4 koja predviđa da će arbitar ceniti postojanje prijateljskog poravnanja, bez obzira da li ono u celosti odgovara odredbama BAT Covid -19 Uputstava ili ne. ${ }^{23}$ Uslov za ovakvo tumačenje postavlja se nisko, jer se od takvog sporazuma očekuje samo da bude bez evidentnih manljivosti.

Konačno, i u pogledu uređenja prijateljskog poravnanja usled pandemije korona virusa postavlja se ograničenje u smislu opsega poravnanja. Graničnik je i ovog puta postavljen na početak „perioda zaključavanja“24

\subsection{RASPODELA RIZIKA I USLOVI ZA RASKID UGOVORA}

Tačka 8 BAT Covid-19 Uputstava jasno određuje da je raspodela rizika, koja predviđa da je samo jedna od strana oštećena, neprihvatljiva u svakom slučaju osim ako je tako nešto nedvosmisleno dogovoreno.$^{25}$ Bez takve odredbe, koja faktički nije

\footnotetext{
${ }^{21}$ Ibid., tačka 2.

22 Ibid., tačka 3.

${ }^{23}$ Ibid., tačka 4.

${ }^{24}$ Ibid., tačka 5.

${ }^{25}$ Ibid., tačka 8.
} 
ni postojala u praksi, negativne posledice pandemije korona virusa moraju biti podeljene između strana, uzimajući u obzir sve činjenice i uslove. U skladu s tim je i davanje dodatne slobode arbitru, mada jasno ograničene, da i u slučaju postojanja klauzule u ugovoru pod koju se mogu podvesti negativni efekti pandemije korona virusa dodatno ceni njenu pravičnost. Ova sloboda arbitra je ograničena, jer on može odstupiti od ovakve klauzule samo ukoliko pronađe da je njom predviđena raspodela rizika značajno nepravična. U svim drugim slučajevima arbitar mora poštovati postojanje takve klauzule. Ipak, ova odredba je, usled apsolutne nepripremljenosti košarkaške industrije na pojavu globalne pandemije korona virusa, od malog praktičnog značaja. Većina ugovora u košarci, van američkog profesionalnog sporta, nisu sadržala takve i slične klauzule.

BAT Covid-19 Uputstva u odeljku 5 još jednom ističu privrženost načelu pacta sunt servanda, na kojem je, uz načelo pravičnosti, i izgrađena praksa visoko cenjenog arbitražnog tribunala. ${ }^{26} \mathrm{U}$ skladu sa načelom pacta sunt servanda za BAT nije prihvatljivo nikakvo unilateralno raskidanje ugovora, niti ugovori automatski prestaju da važe samom činjenicom izbijanja pandemije korona virusa. Ponovo su Uputstva, kao i u ostalim pitanjima, graničnim svoje primene stavila na početak „perioda zaključavanja“. Svako ranije raskidanje ugovora smatraće se raskidanjem u opštem smislu, bez obzira na izbijanje pandemije korona virusa. U skladu s tim se, na takve raskide ugovora, primenjuju opšta pravila iz BAT pravila arbitraže.

U pogledu trajanja ugovora BAT Covid-19 Uputstva su predvidela rešenje po kojem se važeći ugovor iz sezone 2019/20. produžava za period do odigravanja poslednjeg meča sezone, u slučaju da su takmičenja nastavljena. ${ }^{27}$ Ovo pravilo ne važi u slučaju da je iz ugovora jasno da je on potpisan sa jasnom intencijom kraćeg trajanja od kraja sezone, ili u slučaju da bi ovo produženje ugovora bilo značajno nepravično. Posebna pažnja je, u tački 13, posvećena slučajevima kada je igrač ili član stručnog štaba već potpisao ugovor za sezonu 2020/21. sa drugim timom, a situacija nameće produženje obaveza sa onim u kojem ga je pandemija korona virusa zatekla. U tom slučaju, potrebno je da oba kluba postupe u dobroj veri i da spor reše prijateljskim poravnanjem, uzimajući u obzir interese oba kluba na proporcionalan i pravičan način. ${ }^{28}$

\footnotetext{
${ }^{26}$ Ibid., tačka 9.

${ }^{27}$ Ibid., tačka 12.

${ }^{28}$ Ibid., tačka 13.
} 


\subsection{UGOVORNE OBAVEZE KLUBOVA}

Klubovi su dužni da brinu o svojim igračima i trenerima. Posebno, klubovi bi trebalo da apliciraju za svaku dostupnu finansijsku pomoć u cilju smanjenja negativnih efekata pandemije na plate igrača i trenera. Povreda ove dužnosti se uzima u obzir od strane arbitara u potencijalnom postupku pred Tribunalom. ${ }^{29}$

Ugovorne obaveze klubova prema neposrednim proizvođačima, igračima i članovima stručnog štaba, sastoje se od tri elementa: plate kao najbitnijeg dela, bonusa i propratnih stavki (stana, auta, obroka i zdravstvenog osiguranja). BAT Covid-19 Uputstva su najviše pažnje posvetila najbitnijem elementu - zaradama igrača i trenera, dok su propratne stavke postavljene kao podrazumevane. U tački 16 detaljno je uređeno prihvatljivo postupanje klubova prema svojim finansijskim obavezama. Na ovom mestu je, posredno, još jednom ukazano na osnovna načela rada ovog arbitražnog tribunala ex aequo et bono i pacta sunt servanda. Načelo pravičnosti je posebno naznačeno u prvom odeljku tačke 16 gde se pravi distinkcija između zarada igrača i dozvoljenog smanjenja usled pandemije korona virusa. Granica između zarada postavljena je na iznosu od 2.500 evra mesečno. Za zarade do tog iznosa predviđeno je dozvoljeno smanjenje od 0-20\%, dok je za plate iznad tog iznosa početna pozicija postavljena na $50 \%$, a u oba slučaja postupajućim arbitrima dato je nekoliko uputnica u određivanju pravičnog iznosa smanjenja. ${ }^{30}$ Osnovna ideja ovih uputnica je zaštita slabije plaćenih igrača i trenera, kao i onih koji imaju i izdržavaju svoje porodice. Da akcenat nije stavljen samo na stranu igrača, potvrđuju i one uputnice koje u obzir uzimaju pogođenost kluba globalnom pandemijom korona virusa, kao i već pomenuto ponašanje kluba u globalnoj nedaći, gde je standard postavljen na ponašanju u dobroj veri. U slučaju izostanka ovakvog ponašanja kluba, posebno u slučaju diskriminacije (domaćih ili stranih igrača iz sastava), arbitar je pozvan i slobodan da ovo ponašanje adekvatno oceni. Dodatno, postavljen je i ekonomski element u uputnice u kojem se traži ratio ovog smanjenja plata, odnosno da li je takav postupak opravdan i u skladu sa načelom proporcionalnosti - odnosno da li takva ušteda klubu znači u smislu zadržavanja pozitivnog finansijskog bilansa (likvidnosti).

I u pogledu ugovornih obaveza postavljena je distinkcija između situacije koja je podrazumevala konačan prekid sezone i one sa nastavkom sezone nakon perioda zaključavanja. U drugom slučaju postavljeno je ograničenje smanjenja plata na $50 \%$ i obaveza da one budu svakako više od slučaja da se sezona nikako ne nastavlja. ${ }^{31}$ I ovakvo rešenje može biti pozitivno ocenjeno, jer je u obzir uzet udarac prema finansijskoj stabilnosti kluba u oba slučaja, ali među njima nije povučen znak

\footnotetext{
${ }^{29}$ Ibid., tačka 17.

${ }^{30}$ Ibid., tačka 16 (a).

${ }^{31}$ Ibid., tačka 16 (c).
} 
jednakosti. Konačno, i u pogledu plata postavljeno je ograničenje ovim BAT Covid19 Uputstvima na koje mesečne zarade se ona odnose. Ovakvom smanjenju plata ne podležu one mesečne zarade nastale pre perioda zaključavanja. Ipak, naplaćivanje ovih potraživanja unekoliko je ograničeno uzimanjem u obzir teškog položaja u kojem su se klubovi našli, pa im se dozvoljava odlaganje plaćanja do $50 \%$ iznosa dugovanja do početka sezone 2020/21, ukoliko je to neophodno zarad očuvanja stabilnosti datih klubova.

\subsection{UGOVORNE OBAVEZE IGRACA, TRENERA I OSTALIH ČLANOVA STRUČNIH ŠTABOVA}

Obaveze igrača i trenera prema klubovima su u odeljku VII BAT Covid-19 Uputstava. Sportske obaveze igrača suspenduju se za čitav period zaključavanja, osim u slučaju da su kolektivne sportske aktivnosti dozvoljene odlukom lokalnih vlasti. ${ }^{32} \mathrm{Za}$ razliku od sportskih aktivnosti, sve druge aktivnosti u klubu na koje su se igrači obavezali potpisivanjem ugovora nisu suspendovane i nastavljaju se po predviđenom redosledu. I u ovom slučaju je postavljeno ograničenje, a odnosi se na odluke lokalnih vlasti u pandemiji.

Druga osnovna obaveza igrača definisana je kako da ostanu zdravi i fizički spremni u toku perioda zaključavanja, a sve u cilju što lakše adaptacije na, u tom trenutku, potencijalni nastavak sezone. ${ }^{33}$ Ova tačka se pokazala od posebnog značaja u državama u kojima su šampionati nastavljeni, posebno Španiji i prvenstvu Nemačke.

Najzad, sama BAT Covid-19 Uputstva ukazala su da se gorepomenuta pravila odnose prvenstveno na neposredne sportske proizvođače, odnosno igrače i trenere, a da će se Tribunal blagovremeno oglasiti po pitanju drugih aktera u sportskoj industriji profesionalne košarke, pre svega agentima. Ova odredba svoj ratio pronalazi pre svega u trenutku nastanka BAT Covid-19 Uputstava, u prvim mesecima pandemije, gde je od posebnog interesa bila brza i efikasna zaštita igrača i trenera kao najugroženijih izbijanjem globalne pandemije.

\section{4) BAT COVID-19 UPUTSTVA U PRAKSI - SURMACZ V. BM SLAM STAL}

Prva odluka Košarkaškog arbitražnog tribunala sa pozivom (upućivanjem) na Covid-19 Uputstva doneta je već u drugoj polovini maja 2020. godine. ${ }^{34}$ Odluka u

\footnotetext{
${ }^{32}$ Ibid., tačka 18.

${ }^{33}$ Ibid., tačka 19.

${ }^{34}$ Greg Surmacz v. BM Slam Stal S.A., BAT 1482/20, https://www.fiba.basketball/bat/awards, 14. maj 2020.
} 
predmetu Surmacz v. BM SLAM Stal se samo posredno poziva i na ranije izložena pravila iz Covid-19 Uputstva, ali je objavljena sa obrazloženjem zbog značaja primene novih Uputstava i razumevanja rezonovanja Tribunala u novonastaloj situaciji. ${ }^{35}$ Sama odluka doneta je u korist igrača, u punom iznosu plata, ali se ne može u tom pogledu uzeti kao uzor za sve buduće odluke, već je od posebnog značaja iz ugla opšteg rezonovanja arbitra, posebno u pogledu zauzimanja stava prema odbrani kluba koja se pozivala na principe force majeure i na rebus sic stantibus, usled globalne pandemije korona virusa. ${ }^{36}$

U konkretnom slučaju principi rebus sic stantibus nisu bili od značaja jer je predmet spora nastao pre izbijanja globalne pandemije, čime se samo pozivanje na ove principe nije isključilo u budućim postupcima pred Tribunalom. Za primenu ovih principa arbitar je zahtevao trenutno važenje ugovora, kao i činjenice koje ukazuju da je različitost u tumačenju ugovornih obaveza nastala nakon „perioda zaključavanja".

Sa druge strane, arbitar je, na iznenađenje, pozitivno ocenio koncept force majeure ali bez konkretnog efekta, u ovom slučaju usled izostanka kauzalne veze između zahtevanih elemenata za primenu ovog koncepta - iznenadnih, neizbežnih i nepredviđenih događaja i nemogućnosti ispunjenja obligacije. Na ovom mestu arbitar je zauzeo i jasan stav, od posebnog značaja za sve slične slučajeve, da načelo pravičnosti ne dozvoljava da se i oni klubovi koji su svoje ugovorne obaveze prekršili pre izbijanja globalne pandemije korona virusa uspešno „brane“ pozivanjem na force majeure. Ovakav stav arbitra je pravno utemeljen i potpuno očekivan, posebno ukoliko se uzme u obzir da je graničnik u svim odeljcima BAT Covid-19 Uputstava postavljen na početak perioda zaključavanja. Teret dokazivanja da je u konkretnom slučaju potrebno primeniti tačku 16 Uputstava je na klubu.

Iako ovaj slučaj ne predstavlja primenu Covid-19 Uputstava u njihovom punom smislu, on daje odličnu osnovu razumevanja rezonovanja Tribunala. Same činjenice slučaja nisu omogućile detaljniju analizu i pravnu argumentaciju, ali su poslužile kao odlična osnova za spuštanje zavese na sve potencijalne šanse klubova da (zlo)upotrebe situaciju sa globalnom pandemijom za sticanje boljeg položaja u postupcima. Na ovaj način je Tribunal zadržao postupanje po načelu pravičnosti,

\footnotetext{
${ }^{35} \mathrm{O}$ ovoj odluci Tribunala pisano je i na specijalizovanim sajtovima za analizu odluka nastalih u okviru sportskog prava. Hubert Radke, "A Review of the Basketball Arbitral Tribunal's First Covid-19 Decision (Surmacz v. BM SLAM Stal)", https://www.lawinsport.com/topics/item/areview-of-the-basketball-arbitral-tribunal-s-first-covid-19-decision-surmacz-v-bm-slam-stal, Law in Sport, 12.3.2021.

${ }^{36}$ Zanimljivo gledište eksperata sportskog prava izloženo je u članku nastalom mesec dana pre donošenja BAT Covid-19 Uputstava. "The Impact of Covid-19 in the world basketball contract disputes", https://www.eurohoops.net/en/euroleague/1041786/the-impact-of-covid-19-inthe-world-basketball-contract-disputes/, Eurohoops, 3.3.2021.
} 
za koje se inače smatra da je osnovno načelo funkcionisanja ove sportske arbitraže, inače najzaslužnije za njenu uspešnost i dobar glas tokom godina postojanja. Tribunal je ujedno ukazao na pravilno pristupanje konceptu force majeure koje je potrebno da bi ovi principi bili usvojeni, a na istom mestu još jednom pokazao neophodne poveznice potrebne za primenu principa rebus sic stantibus. Posredno, Tribunal je zauzeo i jasan stav o drugom osnovnom načelu pacta sunt servanda, načinivši time ovu odluku pravim uzorom budućim odlukama, nevezano za konkretno činjenično stanje, u periodu globalne pandemije korona virusa.

\section{5) ZAKLJUČNA RAZMATRANJA}

Posebna situacija u košarci kao profesionalnom sportu, nametnuta globalnom pandemijom korona virusa, zahtevala je reakciju Košarkaškog arbitražnog tribunala. Pravna nesigurnost i nepostojanje garancija zaštite već potpisanih ugovora za evropsku košarku, koja je i ovako uzdrmana nedostatakom sredstava i sukobom dve glavne organizacije, nije bila opcija. Obe organizacije dale su svoje predloge za razrešavanje krize ugovora nastale pandemijom. ECA i ELPA su svoj sporazum ograničile na najelementarnije tačke, dok je Košarkaški arbitražni tribunal u svojim Uputstvima pažnju posvetio svim pravnim elementima od značaja u (budućim) arbitražnim postupcima i na taj način dosta sveobuhvatno usmerio košarkašku zajednicu u problematičnom trenutku. Van fokusa BAT Covid-19 Uputstava ostali su jedino agenti, kao posredno oštećeni, a rešavanje njihove situacije ostavljeno je za kasniji period.

BAT Covid-19 Uputstva poslužila su kao jasna vodilja i putokaz postupanja Košarkaškog arbitražnog tribunala u slučajevima nepoštovanja ugovora izazvanih pandemijom ili u toku pandemije korona virusa. Ona su relativno brzo objavljena, i što je još važnije, podjednako brzo primenjena u praksi. Upućivanje na ova Uputstva, kao što je ranije izloženo, obavljeno je već u maju mesecu 2020. godine, u predmetu Surmacz v. BM SLAM Stal. Ovaj slučaj i odluka Tribunala nisu pružili osnovu za potpuno razumevanje rezonovanja arbitra, usled samo posrednog pozivanja na BAT Covid-19 Uputstva, ali je temelj u rezonovanju oko nekih najbitnijih stavki postavljen. Profesionalna košarka je značajno pogođena velikom krizom, ali je na ovaj način sačuvana pravna sigurnost i uspešna tradicija i praksa Tribunala, koji je stekao veliki ugled u košarkaškom i sportskom svetu još od svog nastanka. Nedvosmisleno, Tribunal, uprkos svim poteškoćama, uspešno gradi i održava reputaciju druge najuspešnije sportske arbitraže na svetu.

Košarkaški arbitražni tribunal je zadržao maksimalno poštovanje svojih osnovnih načela i u pandemiji korona virusa, gde su sva BAT Covid-19 Uputstva koncipirana po načelima ex aequo et bono i pacta sunt servanda. Posebnu pažnju Tribunal je posvetio vremenskom ograničavanju važenja Covid-19 Uputstava, jasno im dajući ograničeni karakter i primenu, čime je postavljena ograda i zaštita naspram naširoko primenjivanih i slavljenih BAT arbitražnih pravila. Ovakvo 
ograničenje bilo je neophodno zarad jasnosti, a BAT Covid-19 Uputstva su u svakom odeljku zadržala decidno tumačenje perioda zaključavanja. Prioritet prijateljskog poravnanja je takođe zadržan, a arbitri su dodatno pozvani da sa velikom slobodom ocenjuju postupanje klubova u trenucima izuzetne krize izazvane globalnom pandemijom korona virusa.

Pandemija je dovela do velikih poremećaja u košarci kao profesionalnom sportu, a gotovo se sa sigurnošću može zaključiti da košarka nikada više (barem ne u dogledno vreme) neće biti ista. Ekonomski, marketing i medijski stručnjaci su na ove promene već reagovali (posebno u SAD, Kanadi i Australiji) i štetu izazvanu globalnom pandemijom korona virusa sveli na mnogo manju meru nego što je inicijalno predviđano. „Baloni“ u kojima su se organizovala takmičenja, kako u NBA tako i određenim evropskim ligama, pokazali su se kao prva linija za spas sporta. I ova organizacija je, kao i ostali sporni elementi, adekvatno predviđena BAT Covid19 Uputstvima, gde je posebna pažnja posvećena produžetku važenja ugovora za slučaj nastavka sezone. Pored ovih faktičkih izmena, košarka je doživela i promene realizovanja internet/TV prenosa, kao i ukupnog rada medija.

Konačno, može se zaključiti da su BAT Covid-19 Uputstva (ECA/ELPA sporazum u manjoj meri) značajno raščlanili pravnu situaciju nastalu globalnom pandemijom korona virusa i pružili dobru osnovu za razumevanje na koji način će biti zaštićeni neposredni sportski proizvođači, a sa druge strane i sami klubovi. Njihova pozicija i ekonomski udari kojima su bili izloženi, takođe su uzeti u obzir. Na taj način, BAT Covid-19 Uputstva pokazala su se kao sveobuhvatni neobavezujući dokument, koji je ka odgovorima usmerio mnoge koji su se našli u pravnim nedoumicama u trenucima najveće neizvesnosti i krize.

\section{6) LITERATURA}

Andonović, Stefan, Bajović, Uroš, „Postupak pred košarkaškim arbitražnim tribunalom (BAT)“, Strani pravni život, 62(2), 2018, str. 203-219.

Hasler, Erika, "The Basketball Arbitral Tribunal - An Overview of Its Process and Decisions", in: Antoine Duval and Antonio Rigozzi (eds.), Yearbook of International Sports Arbitration 2015, Hague, 2016, pp. 111-152.

Keshar, Sara, Dickson, Geoff, Ahonen, Aila, "The Effects of Coronavirus Pandemic on the Sports Industry: An Update", Ann Appl Sport Sci 9(1): e964, 2021, pp. 1-23. 
Evropsko zakonodavstvo, br. 75/2021

\section{LEGAL ASPECTS OF THE COVID-19 PANDEMIC AND IMPACT ON THE PROCEEDINGS BEFORE BASKETBALL ARBITRAL TRIBUNAL (BAT)}

Summary: The coronavirus global pandemic has endangered basketball as a professional sport. Contractual Obligations have been shaded by the uncertainty of the global situation, and in that sense, many questions arose. The Basketball Arbitral Tribunal offered some answers to the situation quickly and paved some directions. The Basketball Arbitral Tribunal is an international arbitration body formed to resolve contractual disputes arising in the basketball sports industry. The BAT is already a significantly celebrated arbitration that has given a great contribution to the regulation of legal relations in basketball as a professional sport. New circumstances in the form of a global Covid-19 pandemic have put this arbitration to another important test, and all the results of the work and the solutions offered in the BAT Covid-19 Guidelines are still subject to different opinions and interpretations. The BAT responded to the situation by publishing the BAT Covid-19 Guidelines, which are the main focus of this article. The effects of the BAT before the pandemic are indisputable, and most often its values are described through fast, efficient and safe dispute resolution with simple BAT rules of arbitration, which imply the existence of solutions that speed up and simplify the procedure, all built around many factors. Before the global coronavirus pandemic, a respectable practice in resolving disputes was built, and a similar practice was continued based on the use of instructions published in the first two months of the pandemic.

Keywords: Basketball Arbitral Tribunal, BAT Covid-19 Guidelines, International Basketball Federation, BAT Arbitration Rules, ECA and ELPA Agreement. 